GELANGGANG PENDIDIKAN JASMANI INDONESIA
Kolume 1, Nomor 1, Tahun 2017

\title{
PENGEMBANGAN VARIASI LATIHAN SEPAK SILA UNTUK PESERTA EKSTRAKURIKULER SEPAKTAKRAW DI SD NEGERI WONODADI 1 KECAMATAN WONODADI KABUPATEN BLITAR
}

\author{
Umi Qoryatiningtyas \\ M. E. Winarno \\ Mulyani Surendra \\ Fakultas Ilmu Keolahragaan Universitas Negeri Malang \\ Email: Naningstyas@yahoo.com
}

\begin{abstract}
The aimed of this study is to develop variations of soccer practice so that students are easier to learn soccer (sepak sila). The research method used is research and development method. The result of the development of soccer practice in SDN Wonodadi 1 Blitar obtained the following data: (1) The result of expert evaluation in sepaktakraw obtained $100 \%$ percentage and can be used, (2) The result of expert coaching in sepaktakraw obtained percentage $81.25 \%$ and stated can be used, (3) Result of evaluation of media expert obtained by percentage $78,55 \%$ and stated can be used, (5) Result of small group trial obtained 89,71 percentage and expressed can be used, (6) result of large group trial obtained percentage $89,06 \%$ And otherwise can be used. It is concluded that the product of variation of soccer practice in SDN Wonodadi 1 Blitar is feasible and practical to use.
\end{abstract}

Keywords: Exercises variations, Takraw, Sepak sila

\begin{abstract}
Abstrak: Tujuan penelitian ini adalah mengembangkan variasi latihan sepak sila agar siswa lebih mudah untuk belajar sepak sila. Metode penelitian yang digunakan adalah metode penelitian dan pengembangan. Hasil pengembangan latihan sepak sila di SDN Wonodadi 1 Blitar diperoleh data sebagai berikut: (1) Hasil evaluasi ahli sepaktakraw diperoleh persentase $100 \%$ dan dinyatakan dapat digunakan, (2) Hasil evaluasi ahli kepelatihan sepaktakraw diperoleh persentase $81,25 \%$ dan dinyatakan dapat digunakan, (3)) Hasil evaluasi ahli media diperoleh persentase $78,55 \%$ dan dinyatakan dapat digunakan, (5) Hasil uji coba kelompok kecil diperoleh persentase 89,71 dan dinyatakan dapat digunakan, (6) Hasil uji coba kelompok besar diperoleh persentase $89,06 \%$ dan dinyatakan dapat digunakan. Disimpulkan bahwa produk variasi latihan sepak sila di SDN Wonodadi 1 Blitar ini layak dan praktis untuk digunakan.
\end{abstract}

Kata Kunci: Variasi latihan, Sepak takraw, Sepak sila

Ekstrakurikuler adalah kegiatan belajar yang dilakukan di luar jam sekolah, dan merupakan kegiatan pengembangan diri siswa. Depdiknas (2005:9) menyatakan bahwa ekstrakurikuler merupakan, suatu wadah untuk mengembangkan bakat dan kreatifitas siswa pada satu atau beberapa kegiatan olahraga tertentu. Kegiatan ekstrakurikuler ini biasanya diadakan di sekolah, mulai dari SD,
SMP dan SMA kegiatan ini untuk meningkatkan kualitas mutu pendidikan.

Sepaktakraw adalah olahraga permainan regu atau tim, yang terdiri dari tiga orang peserta namun demikian keberhasilan suatu regu atau tim itu sangat dipengaruhi keterampilan individu yang bermain dalam regu (tim) tersebut (Sulaiman, 2008:15). "Permainan sepaktakraw adalah permainan 
yang biasanya menggunakan seluruh bagian badan kecuali pada tangan yang mayoritas menggunakan kaki" (Darwis dan Basa, 1992 :58). Dalam permainan sepaktakraw, menyepak (sepakan) adalah sangat penting dan dapat dikatakan kemampuan (sepak sila) merupan ibu dari permainan sepak sila dalam permainan sepaktakraw, karena bola dimainkan terbanyak disepak dengan bagian kaki (Darwis dan Basa, 1992:16).

Sepaktakraw regu (hoop) menurut Sulaiman (2008:53). Adalah duplikat dari permainan circle game yang dimainkan oleh $5+1$ cadangan. Ke 5 (lima) pemain dalam posisi melingkar, sama dengan circle game, memulai permainan dengan didahului lambungan bola dari posisi (1) ke posisi yang lain, (2) posisi mengontrol bola rotan (tidak boleh langsung shooting) dan memberikan ke lawan lain posisi, (3) seterusnya posisi 3 berusaha memasukkan bola ke dalam salah satu dari tiga lubang (ring) di atas. Cara memasukkan bola rotan pada ring di atas yaitu dilakukan sentuhan dengan 8 jenis sepakan atau sentuhan tiap pemain, masingmasing sentuhan hanya boleh memasukkan maksimal 3 kali. (Setiap poin masuk mendapat nilai 10).sepuluh Kemenangan ditentukan komulatif poin yang dihasilkan oleh 5 pemain selama 30 (tiga puluh) menit. Pengantian pemain boleh dilakukan kapan saja tanpa menunggu bola mati.

Sepaktakraw secara umum adalah permainan yang dilakukan oleh dua regu atau tim yang saling beradapan di lapangan dan dipisahkan oleh net yang terbentang membelah menjadi dua bagian. "Setiap regu saling yang berhadapan terdiri dari tiga 3 orang pemain yang mempunyai tugas yang berbeda-beda. Salah satu pemain bertugas sebagai tekong yang berdiri paling belakang serta dua orang lainnya menjadi pemain depan yang berada di sebelah kiri dan kanan yang disebut apit kiri dan apit kanan" (Yusup dkk, 2001:10).

Yusup dkk (2001:10) menyatakan bahwa: Sepaktakraw adalah permainan yang dilakukan di lapangan yang berukuran 13,40 $x 6,10 \mathrm{~m}$ yang dibagi oleh dua garis dan net (jaring) setinggi 1,55 dengan lembar $72 \mathrm{~cm}$ dan lubang jaring sekitar $4-5 \mathrm{~cm}$. Bola yang dimainkan terbuat dari rotan atau plastic (synthetic fibre) yang dianyam dengan lingkaran antara $42-44 \mathrm{~cm}$.
Sepaktakraw ini dimainkan oleh dua regu yang saling berhadapan di lapangan yang dipisahkan oleh net yang membelah lapangan menjadi dua bagian. Permainan ini tidak boleh dimainkan oleh lengan dan tangan, tetapi dimainkan oleh kaki, paha, dada, bahu dan kepala. Ada beberapa teknik dasar yang harus dikuasai dalam sepaktakraw. Menurut Darwis dan Basa (1992:15) Dalam bermain sepaktakraw yang baik seharusnya mempuyai kemampuan dan keterampilan yang sangat baik serta kemampuan yang sangat penting dan sangat perlu pada permainan sepaktakraw. apabila seseorang tidak mempunyai kemampuan itu tidak akan bisa bermain sepaktakraw. Kemampuan yang dimaksud adalah kemampuan siswa untuk dapat menyepak bola dengan menggunakan bagian kaki yang diantaranya; sepak sila, sepak kuda, sepak cungkil, sepak mula, menapak, sepak simpuh, main kepala, mendada, memaha, dan membahu dan lainlain. "Kemampuan dasar di atas itu antara yang satu dengan yang lainnya merupakan satu kesatuan yang tidak bisa dipisahkan" (Darwis dan Basa, 1992:15). "Untuk dapat bermain sepaktakraw dengan baik, seseorang pemain yang merupakan individuindividu dalam regu (tim) harus menguasai teknik-teknik dasar bermain dengan baik" (Sulaiman, 2008:15).

Teknik dalam melakukan gerakan sepaktakraw adalah suatu bentuk kemampuan menyepak dengan menggunakan bagian kaki, memainkan bola dengan bagian kaki dalam (sepak sila), memainkan bola dengan dada, sepak kuda, sepak badek, dengan mendada, dengan memaha, dengan membahu, dan memainkan bola dengan kepala (heading). "suatu kemampuan dasar teknik sepaktakraw tersebut dalam permainan sepaktakraw merupakan satu kesatuan yang tidakakan bisa dipisahkan. Tanpa menguasai teknik dasar sepaktakraw tersebut adalah tidakakan bisa dimainkan dengan baik" (Sunggono, 2008:11).

Menurut Sulaiman (2008:16) sepak sila merupakan teknik dasar sepaktakraw yang paling dominan dalam permainan sepaktakraw, teknik sepak sila adalah ibu dari permainan sepaktakraw. Sepak sila adalah, menyepak bola dengan kaki bagian dalam, yang mana pada saat menyepak posisi kaki pukul seperti orang bersila. Sepak sila 
Umi Qoryatiningtyas, Pengembangan Variasi Latihan Sepak Sila untuk Peserta Ekstrakuri-kuler sepaktakraw di SDN Wonodadi 1 Kecamatan Wonodadi Kabupaten Blitar

digunakan untuk menerima bola, menimang dan menguasai bola, mengumpan, hantaran dan untuk menyelamatkan bola dari serangan lawan.

Sepak sila selain menjadi teknik dasar dalam permainan sepaktakraw juga sebagai kunci dalam melakukan permainan antara lain umpan untuk smash, pasing, dan servis, dan apabila teknik sepak sila dikuasai dengan baik maka akan lebih mudah untuk menerima bola dari serangan lawan. Untuk menguasai permainan sepaktakraw peserta ekstrakurikuler diharapkan menguasai teknik dasar, melakukan latihan dengan disiplin dan teratur sejak usia dini, seorang pelatih sepaktakraw harus berusaha untuk meningkatkan prestasi yang ingin di capai atletnya semaksimal mungkin, untuk itu pelatih perlu menyusun program latihan dengan model latihan yang bervariasi yang bertujuan untuk menghindari kebosanan atlet dalam latihan.

Sepak sila merupakan teknik dasar yang paling dominan dalam permainan sepaktakraw, sehingga sebagian orang menyebut teknik sepak sila adalah ibu dari permainan sepaktakraw (Sulaiman, 2008:16). Sepak sila adalah teknik menyepak bola takraw dengan menggunakan salah satu kaki bagian dalam yang ditekuk meyerupai posisi bersila sedangkan kaki yang lain menjadi tumpuan (Hakim dkk, 2007:15). Sepak sila adalah menyepak bola dengan menggunakan kaki bagian dalam, sepak sila digunakan untuk menerima, menimang (menguasai) bola, mengumpan (antaran bola), dan menyelamatkan serangan lawan (Darwis dan Basa, 1992:16).

Sepak sila merupakan teknik dasar yang paling dominan dalam permainan sepaktakraw, sehingga sebagian orang menyebut teknik sepak sila adalah ibu dari permainan sepaktakraw (Sulaiman, 2008:16). Sepak sila adalah teknik menyepak bola takraw dengan menggunakan salah satu kaki bagian dalam yang ditekuk meyerupai posisi bersila sedangkan kaki yang lain menjadi tumpuan (Hakim dkk, 2007:15). Sepak sila adalah menyepak bola dengan menggunakan kaki bagian dalam. Sepak sila digunakan untuk menerima dan menimang (menguasai) bola, mengumpan (antaran bola), dan menyelamatkan dari serangan lawan (Darwis dan Basa, 1992:16).

Melakukan permainan sepaktakraw harus dapat menguasai teknik dasar khusus dalam sepaktakraw. Teknik dasar khusus yang harus dikuasai, yaitu: (1) sepak mula, (2) sepak sila, (3) smash, (4) blok. Teknikteknik dasar tersebut akan dijabarkan sebagai berikut:

Menurut Hakim dkk (2007:23) sepak mula adalah sepakan yang digunakan tekong ke arah lapangan lawan. Sepak mula servis adalah merupakan teknik khusus terpenting dalam sepaktakraw karena angka dapat diperoleh oleh regu yang melakukan sepak mula. Sulaiman (2008:22) menyatakan bahwa sepak mula yaitu sesuai dengan namanya adalah teknik dasar sepakan yang dimaksudkan memulai (membuka) suatu permainan atau pertandingan. Sepak mula bisa dilakukan oleh pemain yang disebut "tekong" yaitu pemain yang melakukan servis berada di tengah belakang. Darwis dan Basa (1992:61) menyatakan sepak mula atau servis adalah sepakan yang dilakukan oleh tekong ke arah lapa-ngan lawan sebagai cara memulai perma-inan sepak mula atau service merupakan cara kerja yang penting dalam sepaktakraw.

Smesh adalah teknik gerak serangan yang biasanya dilakukan untuk mematikan permainan lawan dengan menggunakan kaki dan gerakan tertentu (Hakim dkk, 2007:25). Serangan atau smash adalah pukulan bola yang keras dan tajam ke arah bidang lapangan lawan atau musuh, smesh dalam melakukan permainan sepaktakraw yaitu dapat dilakukan oleh bagian punggung kaki, kaki bagian luar, kaki bagian dalam dan telapak kaki (Sulaiman, 2008:31).

Block adalah gerakan yang dilakukan untuk menahan bola atau mengembalikan bola lawan baik yang berasal dari smesh atau heading dengan posisi pemain yang melakukan blok mendekati jaring (Hakim dkk, 2007:28). Block atau menahan serangan dalam olahraga sepaktakraw biasa dilakukan dengan mengunakan seluruh anggota badan kecuali tangan, block bisa dilakukan menggunakan seluruh tungkai dari kaki sampai pangkal paha, pantan, dan punggung badan (Sulaiman, 2008:35). Sedangkan menurut yusuf (2001:42)

Blocking dalam sepaktakraw dapat dilakukan dengan tungkai, bdanbagian belakang, serta pemain berdiri pada kedua kaki dan pemain mempertahankan bola yang biasa dimainkan oleh lawan di daerahnya, pada waktu bola brada di bibir 
net lawan melakukan lompat bersamaan dengan pemain lawan yang akan melakukan semesh, badan pemaian yang akan memblock melakukan lompat bersamaan dengan pemain lawan yang akan melakukan smesh, badam pemain yang akan memblock smesh diputar dengan harapan bola akan menyentuh punggungnya dan memantulkan kembali ke daerah lawan, badan pemain yang akan memblock smesh diputar dan mengangkat salah satu tungkainya sehingga berada di bibir net dengan harapan bola menyentuh tungkai sehingga bola memantul kembali ke daerah lawan, fungsi block adalah sebagai alat pertahanan untuk menggagalkan serangan lawan.

Menurut Yusup dkk (2001:31) bentuk latihan sepak sila adalah: 1) berdiri pada kedua kaki menghadap ke arah datangnya bola, 2) berdiri pada satu kaki, pada kaki kiri atau kaki kanan, 3) bila berdiri pada kaki kiri, maka kaki kanan ditarik ke atas dan telapak kakinya menghadap lutut kaki kiri kemudian diturunkan setinggi mata kaki, kaki kiri ditarik lagi ke atas sampai setinggi lutut dilakukan berulang-ulang, 4) pemain berdiri pada dua kaki, kaki kiri di depan kaki kanan, berat badan ditumpu pada kaki kiri, menghadap pelambung bola, 5) bola lambung diikuti dengan arah pandangan mata, dan sehingga pemain mengetahui arah bola dan memprediksi kecepatan bola dan jatuhnya bola, 6) kedatangan bola disambut dengan posisi kaki sepak sila, bola diarahkan kembali kepada pelambung, 7) jarak antara pelambung ke penerima dimulai $2 \mathrm{~m}$ setelah melambungnya terarah dan tepat kepelambung di tempat dia berdiri maka jaraknya dapat diperjauh, 8) arah bola dapat diubahubah. Misalnya ke kiri atau ke kanan pelambung, ke atas kepala dan ke atas jauh ke belakang si pelambung bila hal ini dapat dilakukan maka pemain itu dapat dinilai sudah menguasai teknik sepak sila.

Sepak sila adalah gerakan dasar sepaktakraw yang sulit untuk dilakukan. Untuk mengatasi itu diperlukan pembelajaran yang menarik dan menyenangkan. Salah satu cara yang dapat digunakan adalah dengan cara mengembangkan variasi latihan sepak sila untuk merangsang gerak dan mempermudah siswa untuk melakukan gerakan sepak sila.
Menurut Budiwanto (2012:16) latihan adalah melakukan kegiatan olahraga yang dilakukan oleh atlet berdasarkan program latihan yang disusun secara sitematis, bertujuan untuk meningkatkan kemampuan atlet dalam upaya mencapai prestasi yang semaksimal mungkin, terutama biasa dilaksanakan untuk persiapan menghadapi suatu pertandingan. Pasurney (2001:103) menyatakan bahwa latihan adalah proses yang sistematis yang harus menganut prinsip-prinsip latihan yang sehingga organisasi dan mekanisme pada neurophysiological atlet akan selalu berbentuk dengan baik.

Menurut Bompa (1983:2) latihan adalah proses yang amat kompleks yang melibatkan variabel-variabel internal serta eksternal, antara lain motivasi atlet dan ambisi atlet, kuantitas dan kualitas, volume dan intensitas latihan serta suatu pengalamanpengalaman. Harsono (1993:102) menyatakan bahwa dalam proses latihan merupakan proses yang sistematis dalam mempersiapkan atlet pada tingkat tertinggi penampilannya yang biasa dilakukan secara berulang-ulang dengan beban yang semakin tinggi atau meningkat.

Variasi latihan membutuhkan waktu yang lama untuk mendapat adaptasi fisiologis yang bermanfaat, sehingga ada ancaman terjadinya kebosanan dan latihan yang monoton (Budiwanto, 2012:22). Atlet harus memiliki kedisiplinan latihan, tetapi mungkin yang lebih penting adalah memelihara motivasi dan perhatian dengan melakukan variasi pada latihan fisik dan latihan lainya secara rutin (Budiwanto, 2012:21).

Menurut Pasurney (2001:103) prinsip dalam latihan adalah sebagai berikut: (1) overload, (2) konsistensi, (3) spesifikasi, dan empat adalah (4) progresif, individualitas. Menurut Bompa (1983:29) prinsip-prinsip program latihan adalah sebagai berikut: Prinsip beban bertambah prisip spesialisasi (specializatiaon), prinsip pero-rangan, prinsip variasi (variety), prinsip beban meningkat bertahap (progressive in-crease of load), prinsip perkembangan multilateral (multilateral development), prinsip pulih asal, prinsip reversibilitas (reversibility), prinsip beban latihan berlebih, prinsip melampaui batas latihan (the abuse of training), prinsip aktif 
Umi Qoryatiningtyas, Pengembangan Variasi Latihan Sepak Sila untuk Peserta Ekstrakuri-kuler sepaktakraw di SDN Wonodadi 1 Kecamatan Wonodadi Kabupaten Blitar

partisipasi dan prinsip-prinsip latihan menggunakan model.

Program latihan perlu disusun dengan memperhatikan prinsip-prinsip dasar latihan melalui tahapan, teratur dan sistimatis, serta berkesinambungan (kontinyu) dalam sepanjang tahun, pembebanan latihan (training load) yang selalu meningkat dan bertahap setiap tahun (Pasurney, 2001:103). Program latihan yang baik harus dapat memberikan teknik-teknik latihan program latihan harus disusun berdasarkan prinsip-prinsip tertentu yaitu: overload, konsistensi, spesifikasi, progresif, individualitas.

Menurut Gustiana (2011:1) permainan modifikasi adalah perubahan dalam permainan dari teknik bermain yang baku menjadi teknik yang sederhana, sesuai dengan kerakteristik yang dimiliki oleh anak usia dini. "Modifikasi yang dilakukan bisa dari segi bentuk permainan, peraturan, alat, jumlah pemain, dan lama permainan" (Bahagia, 1988:2). Modifikasi dalam mata pelajaran pendidikan jasmani diperlukan dengan tujuan agar siswa memperoleh kepuasan dalam mengikuti kegiatan pembelajaran. Meningkatkan kemungkinan keberhasilan dalam berpartisipasi siswa atau atlet dapat melakukan pola gerak secara benar. Pendekatan modifikasi latihan ini dimaksudkan agar materi yang ada didalam kurikulum dapat disajikan sesuai dengan tahapan-tahapan perkembangan kognitif, afektif dan psikomotorik anak.

Upaya untuk mengatasi kebosanan dan latihan-latihan yang monoton diharapkan pada pelatih untuk lebih kreatif dengan memiliki banyak kreasi pengetahuan dan berbagai jenis latihan yang memungkinkan dapat bervariasi dan berganti-ganti secara periodik. Keterampilan dan latihan dapat diperkaya dengan melakukan adopsi pola gerakan teknik yang sama atau dapat mengembangkan kemampuan gerak yang diperlukan untuk olahraga (Budiwanto, 2012: 22). Menurut Winarno (2013:57) "mengembangkan suatu produk diperlukan persiapan, perencanaan yang amat matang.

Berdasarkan hasil observasi awal yang dilakukan peneliti pada tanggal 6 Februari 2015 di SDN Wonodadi 1 Kecamatan. Wonodadi Kabupaten, Blitar ini kepada peserta ektrakurikuler sepaktakraw khusus penguasaan teknik dasar sepak sila masih banyak peserta ekstra yang melakukan ke- salahan, terutama pada saat menimang bola, siswa merasa kebingungan melakukan gerakan sepak sila. Hal ini ter-bukti dari hasil pengamatan tanggal 6 Februari 2015 yang peneliti lakukan dan wawancara kepada pelatih (Pembina), dan melakukan tes sepak sila dan heading pada peserta ekstrakurikuler sepaktakraw di SD Negeri Wono-dadi 1 Blitar.

Dari 30 (tiga puluh) siswa yang melakukan tes setiap siswa diberikan 10 kali kesempatan dalam melakukan gerakan sepak sila dan heading dengan kriteria sesuai dengan langkah-langkah gerakan yang benar, dari hasil tes tersebut dapat diperoleh data persentase sebagai berikut: siswa melakukan gerakan sepak sila deng benar sejumlah 131 (seratus tiga puluh satu) dengan persentase $43,66 \%$, sedangkan siswa yang melakukan kesalahan sejumlah 169 dengan persentase $56,33 \%$ sedangkan siswa melakukan gerakan heading dengan benar sejumlah 153 dengan persentase 51\% sedangkan siswa melakukan kesalahan sejumlah 147 dengan persentase $49 \%$.

Berdasarkan data hasil observasi tersebut peneliti memberikan solusi permasalahan berupa "Pengembangan Variasi Latihan Sepak Sila untuk Peserta Ekstrakurikuler sepaktakraw di SDN Wonodadi 1 Kecamatan Wonodadi Kabupaten Blitar".

Tujuan penelitian ini adalah dapat menambah mengembangkan variasi latihan sepak sila agar siswa lebih mudah untuk belajar sepak sila. Siswa lebih antusias untuk melakukan sepak sila dan lebih mudah untuk melakukan teknik dasar sepak sila sesuai dengan standar kompetensi yang ditentukan.

\section{METODE}

Metode penelitian yang digunakan dalam penelitian ini adalah metode penelitian dan pengembangan. Model pengembangan yang diterapkan adalah model konseptual, yaitu model yang bersifat analisis yang memberikan komponen-komponen produk yang akan dikembangkan serta keterkaitan antar komponen Dick dan Carey, 1985).

Prosedur penelitian dan pengembangan yang dilakukan merujuk pendapat Borg and Gall (1983:775) yang terdiri dari 10 langkah 
antara lain: (1) Melakukan penelitian dan pengumpulan informasi (kajian pustaka, pengamatan kelas, persiapan laporan pokok persoalan), (2) Melakukan perencanaan (pendefinisian keterampilan, perumusan tujuan, penentuan urutan pengajaran, dan uji coba skala kecil), (3) Mengembangkan bentuk produk awal (penyiapan materi pengajaran, penyusunan buku pegangan, dan perlengkapan evaluasi), (4) Melakukan uji coba lapangan permulaan (dilakukan pada 2-3 sekolah, penggunaan 6-12 subjek), (5) Melakukan revisi terhadap produk utama (sesuai dengan saran-saran dari hasil uji lapangan permulaan), (6) Melakukan uji lapangan utama (dengan 5-10 sekolah dengan 30-100 subjek), (7) Melakukan revisi produk (berdasarkan dari saran-saran dan hasil uji coba lapangan utama), (8) Uji lapangan meliputi 10-30 sekolah dengan 40400 subjek, (9) Revisi produk akhir, (10) Diseminasi dan implementasi (dissemination and implementation).

Dari 10 langkah penelitian dan pengembangan yang dijelaskan di atas, tidak secara keseluruhan digunakan oleh peneliti melainkan hanya mengambil 7 langkah, karena pertimbangan waktu dan biaya yang dimiliki. Metode penelitian tersebut dimodifikasi dengan mengacu pada teori Ardhana (2002:9) yang menjelaskan bahwa pada setiap pengembangan tentu saja dapat memilih dan menentukan langkah-langkah yang paling tepat bagi dirinya berdasarkan kondisi khusus yang dihadapinya pada saat proses pengembangan. Peneliti hanya melakukan penelitian sampai penyempurnaan produk uji coba lapangan (akhir), di samping itu pula peneliti tidak sampai melakukan uji efektivitas (uji kelompok yang lebih besar) dan tidak melakukan desiminasi (seminar) hasil penelitian.

Instrumen yang digunakan dalam penelitian dan pengembangan ini berupa kuesioner yang diberikan kepada peserta ekstrakurikuler sepaktakraw pada saat tahap penelitian awal (analisis kebutuhan), pada saat uji ahli untuk mengetahui kelayakan isi produk pengembangan dan pada tahap penilaian atau tanggapan peserta ekstrakurikuler sebagai calon pengguna produk tentang pengembangan variasi permainan dalam latihan sepak sila yang dibuat.
Jenis data yang digunakan dalam penelitian dan pengembangan ini merupakan data kuantitatif dan kualitatif. Data kuantitatif diperoleh dari penelitian awal berupa angket analisis kebutuhan yang diberikan kepada satu pelatih ekstrakurikuler sepaktakraw dan peserta ekstrakurikuler sepaktakraw. Data kuantitatif diperoleh dari analisis kebutuhan untuk mengetahui persentase produk yang akan dikembang-kan, hasil evaluasi ahli, data hasil dari uji coba kelompok kecil, dan data hasil uji coba kelompok besar. Data kualitatif merupakan data dari berbagai tinjauan para ahli yaitu ahli atletik, ahli sepaktakraw, ahli kepelatihan sepaktakraw dan ahli media.

Subjek evaluasi terdiri dari satu orang ahli sepaktakraw, satu orang ahli kepelatihan sepaktakraw dan satu orang ahli media. Subjek uji coba uji coba kelompok kecil adalah perwakilan dari peserta dengan total 8 siswa. Subjek uji coba kelompok besar adalah perwakilan dari peserta dengan total 22 siswa.

Teknik analisis data yang digunakan dalam penelitian ini menggunakan teknik analisis data kualitatif dan kuantitatif. Untuk analisis kuantitatif menggunakan teknik analisis deskriptif persentase. Analisis kualitatif ini digunakan untuk menganalisis hasil pengumpulan data yang diperoleh dari wawancara dan masukan dari para ahli. Analisis deskriptif yang berupa persentase digunakan untuk menganalisis hasil coba baik uji ahli maupun kelompok. Untuk pemaknaan data peneliti menggunakan persentase yang terdapat pada tabel berikut:

\section{Tabel 1. Taraf Persentase}

\begin{tabular}{ll}
\hline Persentase & Keterangan \\
\hline $81-100 \%$ & Baik Sekali \\
$61-80 \%$ & Baik \\
$41-60 \%$ & Cukup \\
$21-40 \%$ & Kurang \\
$<21 \%$ & Kurang Sekali \\
\hline
\end{tabular}

(Sumber: Arikunto dan Jabar, 2010:35)

\section{HASIL}

Berdasarkan hasil pengumpulan data yang sudag diperoleh dari hasil analisis kebutuhan awal, evaluasi ahli dan uji coba akan disajikan pada bagian. Evaluasi produk yang telah dilakukan oleh 3 orang ahli yaitu: 
Umi Qoryatiningtyas, Pengembangan Variasi Latihan Sepak Sila untuk Peserta Ekstrakuri-kuler sepaktakraw di SDN Wonodadi 1 Kecamatan Wonodadi Kabupaten Blitar

ahli sepaktakraw, ahli kepelatihan sepaktakraw, dan ahli media. Data hasil uji coba terdiri dari uji coba kelompok kecil serta uji coba kelompok besar yang diperoleh dari peserta ekstrakurikuler di SD Negeri Wonodadi 1 Blitar dengan cara mengisi kuisioner yang telah diberikan.

\section{Analisis Kebutuhan}

Data analisis kebutuhan ini diperoleh dari wawancara kepada pelatih sepaktakraw serta melakukan observasi awal kegiatan siswa peserta ekstrakurikuler sepaktakraw dengan jumlah 30 peserta, pada tanggal 06 Februari 2015. Berdasarkan data yang diperoleh dari analisis kebutuhan siswa dan pelatih, diperoleh hasil analisis data sebagai berikut ini: (1) pelatih memberi jawaban bahwa sepak sila adalah kendala yang paling sulit untuk dilakukan oleh peserta ekstrakurikuler sepaktakraw (2) 43,66\% siswa melakukan gerakan sepak sila dengan benar, (3) 53,33\% siswa melakukan gerakan yang salah dalam melakukan sepak sila , (4) $51 \%$ siswa melakukan gerakan heading dengan benar, (5) 49\% siswa melakukan kesalahan dalam melakukan heading. Pelatih menyetujui jika peneliti mengembangkan variasi latihan dengan media buku panduan.

\section{Pengembangan Produk}

Produk yang dibuat berupa variasi permainan yaitu (1) Variasi Latihan Sepak Sila Tanpa Bola, (2) Variasi Latihan Sepak Sila Satu Kali Sentuhan, (3) Variasi Latihan Bola Gantung Bola Rotan, (4) Variasi Latihan Bola Gantung Bola Standar sepaktakraw, (5) Variasi Latihan Berpasangan Bola Dipassing dengan satu kali pegang, (6) Variasi Latihan Berpasangan Bola Dipassing dengan 3 Kali Sentuhan dan Dipassing, (7) Variasi Latihan Sepak Sila Masuk Holahop dengan satu kali sentuhan, (8) Variasi Latihan Sepak Sila Masuk Holahop dengan dua kali sentuhan.

Produk yang dikembangkan yaitu variasi latihan sepak sila ini dievaluasi oleh 3 ahli yaitu (1) ahli sepaktakraw, (2) ahli kepelatihan sepaktakraw (3) ahli media. Berdasarkan hasil data evaluasi ahli sepaktakraw dapat diperoleh persentase 100\%, hasil data evaluasi ahli kepelatihan sepaktakraw diperoleh persentase $81,25 \%$, hasil data evaluasi ahli media diperoleh persentase $78,22 \%$. Dari hasil evaluasi para ahli dapat disimpulkan bahwa pengem-bangan variasi latihan sepak sila dapat digunakan peserta ekstrakurikuler sepak-takraw di SDN Wonodadi 1 Blitar.

\section{Uji Coba Lapangan}

Uji coba lapangan dilakukan enam kali uji coba kelompok kecil dan lima kali uji coba kelompok besar. Uji coba kelompok kecil ini dilakukan kepada peserta ekstrakurikuler sepaktakraw dengan jumlah 8 orang. Berdasarkan hasil data dapat dijelaskan bahwa hasil yang diperoleh pada uji coba kelompok kecil yaitu $89,71 \%$. Uji coba kelompok besar dilakukan peserta ekstrakurikuler sepaktakraw di SDN Wonodadi 1 berjumlah 22 orang. Berdasarkan hasil data dari uji coba kelompok besar yang dilakukan di SD Negeri Wonodadi ! diperoleh persentase $89,06 \%$.

\section{Hasil Revisi Produk}

Berdasarkan data yang telah diperoleh dari ahli sepaktakraw, ahli kepelatihan sepaktakraw, dan ahli media dan uji coba kelompok kecil maupun uji coba kelompok besar, maka beberapa bagian produk ada yang perlu direvisi. Hal ini untuk menyempurnakan variasi latihan sepaktakraw yang pertama. Adapun hasil revisi berdasarkan para ahli yaitu sebagai barikut:

\section{Revisi Tahap Awal}

Berdasarkan revisi awal pembuatan produk adalah sebagai berikut: (1) Gambar atau ilustrasi permainan terlalu kecil, (2) Perlu diperjelaskan siapa sasaran pembaca pada produk buku panduan ini.

Ringkasan revisi berdasarkan saran para ahli adalah sebagai berikut: (1) variasi yang lebih mudah diletakkan pada urutan yang pertama semakin ke belakang variasi latihan semakin sulit., (2) perlu adanya perubahan pada variasi latihan sepak sila masuk holahup 3 kali sentuhan, (3) perlu adanya perubahan pada tinggi tiang pada variasi latihan sepak sila masuk holahup 3 kali sentuhan yang tadinya $3 \mathrm{~m}$ menjadi 2,5 $m$, (4) Diinformasikan dengan jelas sasaran pembaca atau penerima buku ini.

Berdasarkan uji coba kelompok kecil masukan yang didapat untuk menyempurnakan produk adalah (1) Terdapat cara penerapan yang kurang jelas, (2) Perlu diajarkan variasi latihan pembelajaran teknik 
dasar tolak pesepak sila secara terusmenerus. Pada uji coba kelompok besar tidak ada tambahan ataupun saran, sehingga produk akhir tidak perlu direvisi lagi karena sudah benar dan sudah di perbaiki.

\section{PEMBAHASAN}

Produk pengembangan variasi latihan sepak sila untuk peserta ekstrakurikuler sepaktakraw di SDN Wonodadi 1 Blitar adalah sebuah produk yang dilandasi oleh peneliti berdasarkan analisis kebutuhan kemudian disusun produk pengembangan untuk menjawab kebutuhan tersebut. Spesifikasi dari produk pengembangan latihan sepak sila ini terdapat 8 variasi latihan. Produk yang dihasilkan dalam pengembangan ini yaitu buku panduan tentang variasi latihan teknik dasar sepak sila sepaktakraw. Penyusunan produk pengembangan ini, terdiri dari 40 halaman dengan ukuran kertas A5 $(14,8 \mathrm{~cm} \times 21 \mathrm{~cm})$ yang terdiri dari: (1) Cover, (2) Kata Pengantar, (3) Daftar Isi, (4) Bagian Inti, (5) Daftar Rujukan, (6) Tentang Penulis. Produk pengembangan yang berupa buku panduan variasi latihan ini i memiliki 8 variasi latihan yang di dalamnya terdiri dari tujuan permainan, prosedur pelaksanaan dan gambar-gambar yang menarik. Dalam menyusun buku panduan terdapat prosedur yang harus diperhatikan.

Produk ini sebelum diuji cobakan terlebih dahulu dievaluasi oleh 3 ahli yang terdiri dari ahli sepaktakraw, ahli kepelatihan sepaktakraw, dan media. Hasil dari evaluasi ahli tersebut menjadi acuan peneliti untuk perbaikan terhadap produknya agar menjadi lebih berguna dan bermanfaat.

Berdasarkan data evaluasi dari 3 ahli yaitu ahli sepaktakraw, ahli kepelatihan sepaktakraw, dan ahli media terdapat beberapa revisi terhadap produk yang telah dikembangkan, antara lain: (1) variasi yang lebih mudah diletakkan pada urutan yang pertama semakin ke belakang variasi latihan semakin sulit, (2) perlu adanya perubahan pada variasi latihan sepak sila masuk holahup 3 kali sentuhan, (3) perlu adanya perubahan pada tinggi tiang pada variasi latihan sepak sila masuk holahup 3 kali sentuhan yang tadinya $3 \mathrm{~m}$ menjadi $2,5 \mathrm{~m}$, (4) Diinformasikan dengan jelas sasaran pembaca atau penerima buku ini, (5) Secara keseluruhan materi dalam buku panduan ini sudah bagus.

Berdasarkan data yang diperoleh dari peroleh dari uji coba kelompok kecil terdapat beberapa revisi terhadap rancangan produk yang dikembangkan antara lain: terdapat penjelasan yang sulit dimengerti pada saat praktek. Dalam uji coba kelompok besar tidak ditemukan adanya bagian yang perlu direvisi kembali karena persentse validitas sudah memenuhi standar. Setelah melakukan revisi produk sesuai dengan saran para ahli, uji coba kelompok kecil dan uji coba kelompok besar, peneliti menyadari masih banyak terdapat beberapa kekurangan pada produk yang telah direvisi. Kekurangan tersebut antara lain: (1) Masih memerlukan evaluasi dan uji coba pada subjek yang lebih besar atau lebih luas apabila akan diterbitkan untuk kalangan umum, (2) Dalam penelitian ini hanya mengembangkan variasi latihan sepak sila. Selain terdapat banyak kekurangan-kekurangan, produk ini juga mempunyai beberapa kelebihan antara lain: (1) Produk yang dikembangkan terdapat gambar-gambar yang menarik sehingga dapat menarik minat siswa untuk mempelajari, (2) Dalam produk variasi latihan sepak sila, tidak hanya ada pelaksanaan variasi permainan saja tetapi terdapat keterangan gambar yang menarik, tujuan permainan sepak sila, dan prosedur pelaksanaan sehingga menambah kelengkapan produk.

Uji coba kelompok kecil ini dilakukan 6 kali pertemuan (27 Desember 2015-08 Januari 2016, setiap hari rabu, jumat, minggu. Dari hasil evaluasi uji coba kelompok kecil, diperoleh persentase $89,71 \%$ (dapat digunakan) sehingga variasi latihan sepak sila untuk peserta ekstrakurikuler sepaktakraw di SD Negeri Wonodadi 1 ini dapat digunakan dengan revisi kecil. Produk variasi latihan sepak sila untuk peserta ekstrakurikuler sepaktakraw di SDN 1 Wonodadi dilakukan dengan menarik, aman, mudah, dan bermanfaat sehingga menimbulkan semangat belajar siswa. Dibandingkan dengan hasil analisis data yang dilakukan oleh (Purwanto,2007) Dari hasil evaluasi uji coba kelompok kecil, $n=10$ diperoleh persentase $78,7 \%$ sehingga variasi latihan sepak sila di mahasiswa JIK FIK UM 
Umi Qoryatiningtyas, Pengembangan Variasi Latihan Sepak Sila untuk Peserta Ekstrakuri-kuler sepaktakraw di

dapat digunakan dengan keterangan memenuhi kriteria layak untuk digunakan. Dapat disimpulkan bahwa penelitian ini cukup relevan dengan penelitian terdahulu dikarenakan penelitian ini dapat digunakan dengan rentangan antara $86-100 \%$ dengan keterangan sangat baik dan memiliki makna digunakan tanpa revisi.

Uji coba kelompok besar dilakukan 6 kali pertemuan (10 Januari 2016-22 Januari 2016. Dari hasil evaluasi uji coba kelompok besar, diperoleh persentase $89,06 \%$ (sangat baik atau dapat digunakan) sehingga variasi latihan sepak sila dapat digunakan dengan revisi kecil. Produk model variasi latihan sepak sila di SD Negeri Wonodadi 1 Blitar dilakukan dengan dengan menarik, aman, mudah, bermanfaat bagi siswa dan menimbulkan semangat belajar. Dibandingkan dengan hasil analisis data yang dilakukan oleh (Purwanto, 2015) kegiatan uji coba kelompok besar dilakukan 1 kali pertemuan (4 Maret 2007) di JIK FIK UM Malang. Dari hasil evaluasi uji coba kelompok besar yaitu, diperoleh persentase $78,7 \%$ sehingga pembelajaran variasi latihan sepak sila dalam permainan sepaktakraw di Jurusan IImu Keolahragaan Fakultas IImu Pendidikan Universitas Negeri Malang. Dapat disimpulkan bahwa penelitian ini cukup relevan dengan penelitian terdahulu karenakan penelitian ini dapat digunakan dengan rentangan antara $89,6 \%$ dengan keterangan sangat baik dan memiliki makna digunakan tanpa revisi.

Hasil penelitian ini menunjukkan bahwa produk pengembangan variasi latihan sepak sila, valid dan praktis untuk digunakan oleh peserta ekstrakurikuler sepaktakraw di SDN Wonodadi 1 Blitar. Terbukti dari hasil uji coba kelompok kecil diperoleh persentase $89,71 \%$ (sangat baik) dan uji coba kelompok besar $89,06 \%$ (sangat baik). Produk variasi latihan sepak sila dilakukan dengan dengan menarik, aman, mudah, bermanfaat bagi siswa dan menimbulkan semangat belajar.

Hasil uji coba kelompok kecil dan uji coba kelompok besar di SDN Wonodadi 1 siswa merasa senang karena variasi latihan sepak sila belum pernah dilakukan pada kegiatan proses pembelajaran dasar sepak sila. Produk berupa buku panduan ini terdapat gambar variasi latihan sepak sila. Selain kelebihan yang telah dijelaskan di atas produk ini juga memiliki kekurangan kerena keterbatasan penelitian ini hanya variasi latihan sepak sila untuk peserta ekstrakurikuler sepaktakraw di SDN Wonodadi 1 Blitar.

\section{KESIMPULAN}

Dapat disimpulkan bahwa produk variasi latihan sepak siladi SDN Wonodadi 1 Blitar dapat digunakan siswa sebagai mestinya (valid, sesuai dan tepat, layak digunakan, prkatis). Produk model pembelajaran teknik dasar tolak peluru ini dikemas dalam bentuk buku panduan serta terdapat gambar variasi latihan sepak sila, prosedur pelaksanaan dan tujuan dari pembelajaran yang dilakukan agar siswa merasa senang pada saat proses latihan berlangsung.

\section{SARAN}

Pemanfaatan produk variasi latihan sepak sila sepaktakraw ini perlu mempertimbangkan situasi dan kondisi. Sebelum mempelajarivariasi latihan sebaiknya siswa melihat dan mempelajari bentuk variasi latihan melalui media buku panduan, sehingga siswa dapat mengetahui dan paham tentang bentuk-bentuk variasi latihan yang akan dipelajari dengan sebaik-baiknya sebelum mempraktekkan di lapangan dan guru juga akan dimudahkan dalam proses mengajar.

\section{DAFTAR RUJUKAN}

Ardhana,W. 2002. Konsep Penelitian Pengembangan dalam Bidang Pendidikan dan Pembelajaran. Malang: Universitas Negeri Malang.

Arikunto,S, dan Jabar, A Safruddin C. 2010. Evaluasi Program Pendidikan. Jakarta: PT Bumi Aksara.

Hermawa A H, Susilang, Julaeha $S$, dan Sanjaya W. 2008:12.27. Pengembangan Kurikulum dan Pembelajaran. Jakarta: Universitas Terbuka. 
Bompa, O. 1983. Theory and Methodology of Training. New York: United States of America.

Borg \& Gall. 1983. Education Research: An Introduction. $4^{\text {th }}$ Ed. London: Longman Inc.

Budiwanto, S. 2012. Metodologi Latihan Olahraga. Malang: Universitas Negeri Malang (UM Press).

Bahagia, Y. 1988. Pengembangan Media Pengajaran Penjas. Departemen Pendidikan Nasional Direktorat Jenderal Pendidikan Dasar dan Menengah Direktorat Pendidikan Luar Biasa. (online), /doc/88504332/ Pengembangan-Media Pembelajaran -Penjas-Buku\#).

Darwis, R. \& Basa P. 1992. Olahraga Pilihan Sepaktakraw. Departemen Pendidikan dan Kebudayaan Direktorat Jenderal Pendidikan Tinggi Proyek Pembinaan Tenaga Kependidikan.

Departemen Pendidikan Nasional. 2005. Kurikulum Berbasis Kompetensi. Jakarta: Badan Penelitian dan Pengembangan.

Gustiana, A.D. 2011. Pengaruh Permainan Modifikasi terhadap Kemampuan Motorik Kasar dan Kognitif Anak Usia Dini. (studikuasi eksperimen pada kelompok B TK Kartika dan TK Lab. UPI). Jurnal Pendidikan Jasmani dan Olahraga, 5 (1): hlm: 1, (online), (http://jurnal.upi.edu/ penjasor /view /680/pengaruh-permainan-modifikasiterhadap-kemampuan-motorik-kasar -dan-kognitif-anak-usia-dini\%28studi-kuasi-eksperimen-padakelompok-b-tk-kartika-dan-tk-lab.upi\%29.html).

Hakim, A . A, Sudarso, dan Bulqini, A. 2007. Sepaktakraw. Unesa University Pres.

Harsono. 1988. Coacing and Aspek-Aspek Psikologis dalam Coacing. Jakarta Iptek Pengembangan Lembaga Pendidikan Tenaga Kependidikan.
Pasurney. 2001. Latihan Fisik Olahraga. Jakarta: Pusat Pendidikan dan Penataran Bidang Penelitian dan Pengembangan KONI Pusat Agustus 2001.

Prawirasaputra, S. 2000. Sepaktakraw. Surabaya: Departemen Pendidikan dan Kebudayaan Direktorat Jendral Pendidikan Dasar dan Menengah.

Purwanto. 2007. Pengembangan Variasi Latihan Sepak Sila dalam Permainan Sepaktakraw di Jurusan IImu KeolahragaanFakultas IImu Pendidikan Universitas Negeri Malang. Malang

Setiawan, H. 2007. Pengembangan Variasi Latihan Smes Kedeng Luar dalam Permaianan Sepaktakraw untuk Mahasiswa Jurusan IImu Keolahragaan Fakultas IImu Pendidikan Universitas Negeri Malang. Malang

Sudijono, Anas. 2006. Pengantar Statistik Pendidikan. Jakarta: PT Raja Grafindo Persada.

Suharta, A. 2007. Pendekatan Pembelajaran Bolavoli Mini Sebuah Gagasan Konseptual. Jurnal Pendidikan Jasmani Indonesia. (online), http: //staff.uny.ac.id/sites/default/files/pen elitian/Saryono,\%20S.Pd.\%20Jas.,\% 20M.Or./JPJI\%20April\%202008.PDF. Diakses 08 Mei 2015.

Sulaiman. 2008. Sepaktakraw Pedoman bagi Guru Olahraga, Pembina, Pelatih, dan Atlet. Semarang: Unnes Press.

Sunggono. 2008. Sepaktakraw. Jakarta: Ganeca Exact.

Tim Universitas Negeri Malang, 2010. Pedoman Penulisan Karya IImiah, Edisi Kelima. Malang: Universitas Negeri Malang. 
Umi Qoryatiningtyas, Pengembangan Variasi Latihan Sepak Sila untuk Peserta Ekstrakuri-kuler sepaktakraw di

Winarno, M.E. 2011. Metodologi Penelitian Pendidikan Jasmani. Malang: Universitas Negeri Malang.

Yusup, U. Prawirasaputra, S. \& Usli, L. 2001:132. Pembelajaran Permainan Sepaktakraw Pendekatan Keterampilan Taktis di SMU. Jakarta Pusat: Direktorat Jenderal Olahraga.. 